\title{
EXPERIMENTAL MALARIA IN MAN. II. LIVER FUNCTION ${ }^{1}$
}

\author{
BY ANCEL KEYS, SAMUEL WELLS, ${ }^{2}$ FREDERICK W. HOFFBAUER, ${ }^{3}$ HENRY \\ LONGSTREET TAYLOR, AND AUSTIN HENSCHEL
}

(From the Laboratory of Physiological Hygiene, University of Minnesota, Minneapolis)

(Received for publication July 22, 1949)

It is generally known that malaria may produce signs of impaired liver function. In studies on experimentally induced malaria in this laboratory $(1,2)$, special efforts were made in an attempt to obtain information on four aspects of the question as to the effects on the liver: (1) The magnitude and character of the impairment as indicated by the several methods customarily used in the study of liver disease; (2) the time course of change during continuance of the infection; (3) the relationship of the liver function to the body temperature; (4) the recovery course following termination of the malaria with quinine. The present paper summarizes the findings on these points.

\section{SUBJECTS AND PROGRAM}

The general characteristics of the subjects and the experimental program were described in a preceding paper (2). The 12 volunteer subjects were Conscientious Objectors who were considered to represent well-nourished normal young men in a fair state of physical fitness. Prior to the experiment, emphasis was placed on discovering any indications of previous episodes or history of liver disease. One subject (No. 9) gave a history of illness at the age of 12 which was characterized by an insidious onset with fever, malaise and jaundice of two months' duration, with subsequent full recovery without evidence of residues. Two other subjects had occasionally noted mild indigestion after eating fatty foods. There were no other suggestive points in the histories and no physical abnormalities were found on physical examination. In five subjects the liver could not be palpated. In seven subjects the liver was palpated at the right costal margin on deep inspiration and was apparently of normal texture; the liver was not tender in any of the men.

For three weeks before inoculation the subjects were housed and fed in the laboratory on a standard regimen of moderate activity and a standard "good" diet of 3,600 Cal. with adequate vitamins. At the onset of the first

1 The results reported here were obtained in part under a contract, recommended by the Committee on Medical Research, between the Regents of the University of Minnesota and the Office of Scientific Research and Development.

2 Present address : Jacksonville, Florida.

3 Department of Medicine, University of Minnesota Hospitals. paroxysm the subjects were hospitalized in the Laboratory with full nursing care. Codeine was used for headache as needed. Water was allowed ad lib. and the fluid intake was maintained at or above $3,000 \mathrm{cc}$. daily. The standard "adequate" diet was provided throughout the entire experiment but actual food consumption declined somewhat on the febrile days. During the afebrile periods limited activity, including bathroom privileges, was allowed.

The malaria was terminated in all cases without incident with quinine sulfate and the quinine was continued for 21 consecutive days. There were no relapses or recurrences.

\section{METHODS AND DEFINITIONS}

Plasma bilirubin was estimated by the Ducci-Watson modification (3) of the Malloy-Evelyn method (4). This modification of the quantitative van den Bergh reaction was selected as being particularly useful in evaluating latent jaundice $(5,6)$; previous experiences with this procedure in inoculation malaria have been described $(7,8)$. Urine was analysed for bilirubin with the Harrison strip test (9) and the methylene blue test (10). In a series of control studies it was found that heparinized plasma gave results identical with those obtained on serum for both prompt and total bilirubin and was more satisfactory than either oxalated or citrated plasma. A few trials with freezing plasma and urine samples indicated that subsequent analyses for bilirubin did not agree closely with the results of analyses on the fresh materials so attempts at storage were abandoned. Accordingly, all bilirubin analyses were made on the fresh materials.

For the bromsulfalein excretion test a dosage of $5 \mathrm{mg}$. per kg. of body weight (11) and a 45-minute time interval (12) were employed.

Cephalin-cholesterol flocculation was estimated according to Hanger (13), readings being made at 24 and at 48 hours. The thymol turbidity reaction was estimated with Maclagan's method (14).

Urobilinogen was estimated with the method of Watson et al. $(15,16)$ in urine samples collected over twohour periods. The results are expressed as "Ehrlich Units," one unit being defined as the equivalent of the color intensity produced by $1.0 \mathrm{mg}$. of urobilinogen in pure solution.

The detailed analysis of the paroxysms is aided by defining the several stages as follows: The "onset" is defined as the period of rising temperature at the beginning of a paroxysm when the rectal temperature has 
not yet surpassed $101^{\circ} \mathrm{F}$. The "peak" is the period when the rectal temperature is within one degree (Fahrenheit) of the highest value reached in the paroxysm. The "base" is defined as the period when the rectal temperature has subsided to $101^{\circ} \mathrm{F}$. or less. The "rise" is any time between the onset and the peak; the "fall" is any time between the peak and the base. Any period of six hours or longer between paroxysms is defined as the "interval."

\section{RESULTS}

\section{Clinical course}

Following the intravenous inoculation of $3 \mathrm{cc}$. of blood infected with the McCoy strain of Plasmodium vivax, unmistakable malaria developed in every case. Table I shows the time of onset of the first paroxysm, the number of paroxysms before termination, and the total degree-hours of fever for each man. Three of the 12 men showed the Korteweg initial temperature rise (17); the first true paroxysm began in eight to 154 hours following inoculation.

Subject No. 11 developed a plateau type of fever at $103^{\circ} \mathrm{F}$., with rather indefinite paroxysms. He was not studied to the same extent as the others and was given quinine after four febrile days. Subject No. 19 exhibited prolonged and frequent paroxysms with severe and troublesome epistaxis. All of the other men developed signs and symptoms typical of uncomplicated tertian malaria. No

TABLE I

Duration of the incubation period (Incub.) and summary of the febrile course following malaria inoculation

All temperatures measured per rectum in degrees Fahrenheit. In subjects Nos. 7, 8 and 20, the Korteweg initial temperature rise was observed at, respectively, 11 , 25 and eight hours after inoculation. "Degree-hours" is sum of the products of the number of hours above the specified temperature times the degrees above that temperature for those hours.

\begin{tabular}{c|c|c|c|c}
\hline $\begin{array}{c}\text { Subject } \\
\text { No. }\end{array}$ & Incub. & $\begin{array}{c}\text { No. of } \\
\text { paroxysms }\end{array}$ & \multicolumn{2}{|c}{ Degree-hours } \\
& hrs. & & $101^{\circ} \mathrm{F}$. & $102^{\circ} \mathrm{F}$. \\
7 & 125 & 7 & 196 & 69 \\
8 & 131 & 8 & 198 & 70 \\
9 & 131 & 7 & 246 & 89 \\
10 & 131 & 7 & 193 & 58 \\
11 & 110 & 6 & 172 & 51 \\
15 & 105 & 5 & 221 & 93 \\
16 & 131 & 5 & 216 & 66 \\
17 & 59 & 6 & 179 & 58 \\
18 & 130 & 7 & 198 & 81 \\
19 & 35 & 5 & 164 & 59 \\
20 & 154 & 7 & 147 & 58 \\
Mean & 104.2 & 6.4 & 182 & 64 \\
& & & 192.7 & 68.0 \\
\hline
\end{tabular}

TABLE II

Mean values, with standard deviations, for the one-minute and total plasma bilirubin concentrations (mg. per 100 cc. of plasma), urobilinogen (Ehrlich units per two-hour urine sample), and bromsulfalein (B.S.P.) retention (per cent of injected dose retained at 45 minutes)

All data obtained during the first three paroxysms are combined in the paroxysms 1-3 means; similarly all data for paroxysms 4 through 7 are combined in the paroxysms 4-7 means.

\begin{tabular}{|c|c|c|c|c|c|c|}
\hline \multirow{2}{*}{ Test } & \multicolumn{2}{|c|}{ Control } & \multicolumn{2}{|c|}{$\underset{1-3}{\text { Paroxysms }}$} & \multicolumn{2}{|c|}{$\underset{4-7}{\text { Paroxysms }}$} \\
\hline & Mean & S.D. & Mean & S.D. & Mean & S.D. \\
\hline $\begin{array}{l}\text { One-minute bilirubin } \\
\text { Total bilirubin } \\
\text { Urobilinogen } \\
\text { B.S.P. retention }\end{array}$ & $\begin{array}{l}0.069 \\
0.763 \\
1.161\end{array}$ & $\begin{array}{l}0.055 \\
0.192 \\
0.355\end{array}$ & $\begin{array}{l}0.189 \\
1.391 \\
2.734 \\
8.94\end{array}$ & $\begin{array}{l}0.130 \\
0.501 \\
4.581 \\
6.56\end{array}$ & $\begin{array}{l}0.203 \\
1.601 \\
5.591 \\
11.34\end{array}$ & $\begin{array}{l}0.071 \\
0.583 \\
4.795 \\
8.25\end{array}$ \\
\hline
\end{tabular}

change in liver size was noted at any time. During the febrile period four of the subjects had palpable spleens and the spleen was tender in three of them. It will be observed (Table I) that the total degree-hours of fever of $101^{\circ} \mathrm{F}$., or above, ranged from 164 to 246 before termination.

\section{Plasma bilirubin}

Summarized data on the plasma bilirubin are given in Table II. Detailed data from two typical subjects are given in Tables III and IV. All of the subjects exhibited increases in both one-minute and total plasma bilirubin, the mean values for the group as a whole being significantly higher during malaria for both items than in the control period. The mean values for the later paroxysms (Nos. 4 through 7) were statistically significantly

TABLE III

Detailed protocol for subject No. 6

The units in which the values are expressed are rectal temperature in degrees Fahrenheit, plasma bilirubin in mg. per $100 \mathrm{cc}$. of plasma, B.S.P. in per cent of injected bromsulfalein retained at 45 minutes, and urobilinogen in Ehrlich units excreted in a two-hour urine sample.

\begin{tabular}{|c|c|c|c|c|c|c|}
\hline \multirow[b]{2}{*}{$\begin{array}{c}\begin{array}{c}\text { Paroxysm } \\
\text { No. }\end{array} \\
\\
\\
\text { Control } \\
2 \\
2 \\
2 \\
2 \\
3 \\
4 \\
5 \\
7 \\
\text { First afel }\end{array}$} & \multirow[b]{2}{*}{\begin{tabular}{|l} 
Stage of \\
paroxysm
\end{tabular}} & \multirow{2}{*}{\begin{tabular}{|c|}
$\begin{array}{c}\text { Rectal } \\
\text { tem- } \\
\text { perature }\end{array}$ \\
\\
\\
101 \\
104 \\
100.6 \\
99.8 \\
104 \\
106 \\
105 \\
105.5
\end{tabular}} & \multicolumn{2}{|c|}{ Plasma bilirubin } & B.S.P. & $\begin{array}{c}\begin{array}{c}\text { Urobi- } \\
\text { linogen }\end{array} \\
\begin{array}{c}\text { E.U. pe } \\
\text { two hrs. } \\
1.09\end{array}\end{array}$ \\
\hline & & & $\begin{array}{c}\text { one } \\
\text { min. } \\
0.00 \\
0.094 \\
0.433 \\
0.229 \\
0.157 \\
0.126 \\
0.294 \\
0.078 \\
0.221\end{array}$ & $\begin{array}{l}\text { total } \\
0.59 \\
0.77 \\
1.10 \\
1.56 \\
1.34 \\
0.72 \\
1.10 \\
0.75 \\
1.31 \\
1.59\end{array}$ & $\begin{array}{r}10.6 \\
10.6 \\
9.0\end{array}$ & $\begin{array}{c}\text { E.U. per } \\
\text { two hrs. } \\
1.09\end{array}$ \\
\hline
\end{tabular}


TABLE IV

Detailed protocol for subject No. 7

The units in which the values are expressed are rectal temperature in degrees Fahrenheit, plasma bilirubin in mg. per 100 cc. of plasma, B.S.P. in per cent of injected bromsulfalein retained at 45 minutes, and urobilinogen in Ehrlich units excreted in a two-hour urine sample.

\begin{tabular}{|c|c|c|c|c|c|c|}
\hline \multirow[b]{2}{*}{$\begin{array}{c}\begin{array}{c}\text { Paroxysm } \\
\text { No. }\end{array} \\
\\
\text { Control } \\
1 \\
3 \\
4 \\
4 \\
4 \\
5 \\
7 \\
\text { First afe }\end{array}$} & \multirow{2}{*}{$\begin{array}{c}\begin{array}{c}\text { Stage of } \\
\text { paroxysm }\end{array} \\
\\
\\
\text { rise } \\
\text { peak } \\
\text { onset } \\
\text { peak } \\
\text { base } \\
\text { peak } \\
\text { peak } \\
\text { brile day }\end{array}$} & \multirow{2}{*}{\begin{tabular}{|c|}
$\begin{array}{c}\text { Rectal } \\
\text { tem- } \\
\text { perature }\end{array}$ \\
\\
\\
\\
99 \\
105 \\
100 \\
105 \\
101.6 \\
104.5 \\
106
\end{tabular}} & \multicolumn{2}{|c|}{ Plasma bilirubin } & $\begin{array}{c}\text { B.S.P. } \\
\begin{array}{c}\text { per cent } \\
\text { retention }\end{array}\end{array}$ & $\begin{array}{l}\begin{array}{c}\text { Urobi- } \\
\text { linogen }\end{array} \\
\begin{array}{l}\text { E.U. per } \\
\text { two hrs. }\end{array}\end{array}$ \\
\hline & & & $\begin{array}{c}\begin{array}{c}\text { one } \\
\text { min. }\end{array} \\
0.133 \\
0.126 \\
0.198 \\
0.189 \\
0.125 \\
0.294 \\
0.164 \\
0.253\end{array}$ & $\begin{array}{l}\text { total } \\
1.07 \\
1.00 \\
1.85 \\
2.14 \\
2.18 \\
2.58 \\
1.85 \\
1.91\end{array}$ & $\begin{array}{r}2.4 \\
12.0 \\
10.0\end{array}$ & $\begin{array}{c}\text { E.U. per } \\
\text { two hrs. } \\
1.25 \\
1.43 \\
1.73\end{array}$ \\
\hline
\end{tabular}

higher than in the earlier paroxysms (Nos. 1 through 3).

Watson (18) has reported that the upper limit of normal for the prompt, direct reacting component ("one-minute bilirubin") does not exceed $0.2 \mathrm{mg}$. per $100 \mathrm{cc}$., while the total serum bilirubin (direct plus indirect reacting components) does not exceed $1.0 \mathrm{mg}$. per $100 \mathrm{cc}$. In retention jaundice the total serum bilirubin is elevated principally by an increase in the indirect reacting component; the one-minute bilirubin remains essentially normal. An increase in the one-minute bilirubin, beyond the value of $0.2 \mathrm{mg}$. per $100 \mathrm{cc}$., is quite regularly associated with regurgitation jaundice as a result of liver damage or extrahepatic biliary obstruction. These criteria may be applied to the present findings.

In ten of the 12 subjects abnormal values for the total plasma bilirubin were encountered at some time during the course of the malarial fevers and values above $2 \mathrm{mg}$. were found on one or more occasions in each of six men. The highest value noted (subject No. 7) was $2.58 \mathrm{mg}$. per $100 \mathrm{cc}$. This is scarcely above the range of visible icterus which is usually said to be about $2.0 \mathrm{mg}$. The observed hyperbilirubinemia involved principally an increase in the indirect reacting component and is therefore judged to have been mainly of the retention type. In four subjects (Nos. 6, 9, 10 and 17), however, the one-minute bilirubin at times ranged between 0.319 and $0.74 \mathrm{mg}$. per $100 \mathrm{cc}$. and in these instances, at least, it must be conceded that there was some element of regurgitation jaundice.

\section{Bromsulfalein excretion tests}

Normally, less than 4 per cent of the dye remains in the bloodstream 45 minutes after injection of a test dose of $5 \mathrm{mg}$. of bromsulfalein (B.S.P.) per kg. of body weight (19). During malaria the majority of the values for this test exceeded the 4 per cent limit, the averages being 8.94 for the period of the first three paroxysms and 11.34 for the later paroxysms (Table II). The highest retention value was 31 per cent recorded from subject No. 17.

Eight of the 12 subjects had three or more B.S.P. tests during the course of their malaria. Two of these men (Nos. 15 and 18) showed no real abnormality in this test at any time, three men (Nos. 7, 10 and 17) showed retentions of 15 per cent or more, and the other three men (Nos. 6,8 and 20 ) showed mild degrees of B.S.P. retention. The variation between individuals was considerably greater than the variations within the individuals on different occasions ; in other words, each subject tended to establish his own characteristic pattern in this regard.

Of the four subjects who had less than three B.S.P. tests during malaria, two (Nos. 9 and 19) showed high values ( 8 to 17 per cent retention), while subjects Nos. 11 and 16 gave essentially normal results in single tests.

Taking the group as a whole, there appears to have been little or no relation between the levels of the plasma bilirubin and the degree of bromsulfalein retention, the situation resembling that in many patients with hemolytic anemias in whom retention jaundice may be quite marked though no abnormality of the bromsulfalein excretion is demonstrable. In regurgitation jaundice, it is probable that a correlation of the level of the oneminute bilirubin with the impairment of bromsulfalein excretion can be demonstrated in many instances but in the single patient (subject No. 10) in this series who was considered to have had an appreciable degree of regurgitation, there was no apparent correlation between the degree of bilirubinemia and the B.S.P. retention.

The question of a relation between B.S.P. retention and the body temperature at the time of the test was examined in nine instances where de- 
terminations were made at the peak and were repeated at the base of a paroxysm. This comparison revealed no significant effect of body temperature per se.

After the administration of quinine the B.S.P. retention rapidly returned to normal. Six of the men were tested in the first 24 hours after quinine and the other men were checked in the next several days. All of these post-quinine values were in the normal range so it seems likely that normality was actually regained in 24 hours or less in all cases.

\section{Cephalin-cholesterol and thymol tests}

The upper limit of normal for the thymol turbidity test as used here is said not to exceed 4 units (14). Although this test was applied to 116 serum samples from these 12 subjects, a value of 4 units was only recorded twice and in no case was a higher, i.e., "abnormal" value found. The incidence of specified test results at different times is summarized in Table V. Although this might be considered a totally negative finding, it is notable that consistent changes were observed in every subject. Table VI summarizes the data from which it appears that thymol turbidity increased slightly as malaria continued and was further increased in the first three to six weeks after the termination with quinine; seven to nine weeks after malaria there was still a tendency for the values to be elevated as compared with the control.

In the present study, abnormalities in the Hanger test (cephalin-cholesterol flocculation) did not appear early in the febrile stages, the first considerable change $(2+$ or more) appearing only after three or more paroxysms. In the majority of the subjects the most positive Hanger tests were obtained one or more weeks after the

\section{TABLE $\mathrm{v}$}

Means, and standard deviations, for the thymol turbidity test results with the 12 subjects at different stages

"Early" and "later" malaria values correspond to paroxysms $1-3$, and $4-7$, respectively.

\begin{tabular}{l|c|c|c|c|c}
\hline \hline & \multicolumn{2}{|c|}{ Malaria } & \multicolumn{3}{|c}{ Post-malaria weeks } \\
\cline { 2 - 6 } & Early & Later & $3-4$ & $5-6$ & $7-9$ \\
\hline Mean & 1.00 & 1.54 & 2.08 & 1.79 & 1.42 \\
S.D. (土) & 0 & 0.50 & 0.70 & 0.78 & 0.73 \\
\hline
\end{tabular}

TABLE VI

Cephalin-cholesterol flocculation and thymol turbidity reactions of the serum for combined paroxysms 1 through 3 and 4 through 7, and for seven weeks following the termination of the malaria

The number of sera giving no reaction $=0,1$ or 2 units $=1-2+$, and 3 or 4 units $=3-4+$. In no case were more than 4 units recorded for either test.

\begin{tabular}{|c|c|c|c|c|c|c|c|c|c|}
\hline \multirow{2}{*}{ Test } & \multirow{2}{*}{ Units } & \multicolumn{2}{|c|}{$\begin{array}{c}\text { Par- } \\
\text { oxysm }\end{array}$} & \multicolumn{6}{|c|}{ Weeks after malaria } \\
\hline & & $1-3$ & $4-7$ & 1 & 3 & 4 & 5 & 6 & 7 \\
\hline $\begin{array}{l}\text { 24-hour } \\
\text { Ceph.-cholest. } \\
\text { 48-hour } \\
\text { Ceph.-cholest. } \\
\text { Thymol turb. }\end{array}$ & $\begin{array}{c}0 \\
1+-2+ \\
3+-4+ \\
0 \\
1+-2+ \\
3+-4+ \\
0 \\
1+-2+ \\
3+-4+\end{array}$ & $\begin{array}{r}10 \\
0 \\
0 \\
9 \\
2 \\
0 \\
0 \\
10 \\
0\end{array}$ & $\begin{array}{r}6 \\
3 \\
1 \\
2 \\
5 \\
2 \\
0 \\
12 \\
0\end{array}$ & $\begin{array}{r}0 \\
5 \\
6 \\
0 \\
4 \\
7 \\
0 \\
11 \\
0\end{array}$ & $\begin{array}{r}5 \\
6 \\
0 \\
0 \\
10 \\
1 \\
0 \\
8 \\
3\end{array}$ & $\begin{array}{r}11 \\
1 \\
0 \\
5 \\
7 \\
0 \\
0 \\
9 \\
3\end{array}$ & $\begin{array}{r}10 \\
1 \\
0 \\
7 \\
4 \\
0 \\
0 \\
9 \\
2\end{array}$ & $\begin{array}{l}6 \\
4 \\
1 \\
3 \\
7 \\
1 \\
0 \\
9 \\
2\end{array}$ & $\begin{array}{r}9 \\
3 \\
0 \\
7 \\
4 \\
1 \\
0 \\
10 \\
2\end{array}$ \\
\hline
\end{tabular}

malaria had been terminated and regression to normal in this regard took many weeks in some cases. Test results of $1+$ to $2+$ were recorded in two subjects (Nos. 6 and 19) four months after the malaria was terminated.

\section{Bilirubin and urobilinogen in the urine}

Both the Harrison strip test and the methylene blue test for bilirubin in the urine were uniformly negative in all men at all times. This acholuria is understandable since the jaundice was predominantly of the retention type. This is in contrast with the situation in experimentally induced virus hepatitis where Neefe and Reinhold (5) demonstrated bilirubinuria even before the appearance of hyperbilirubinemia. However, Neefe and Reinhold estimated only the total bilirubin in the blood and it is quite possible that bilirubinuria primarily reflects the bilirubin in the blood which is of the direct (one-minute) reacting type (cf. Watson and Hoffbauer [6]).

In normal man, values for urobilinogen seldom exceed 1.2 Ehrlich units in the two-hour urine (15). During malaria all of the present subjects except No. 11 consistently showed abnormal values according to this criterion. The highest individual values recorded were 18.0 and 22.1 units from subject No. 9 for the peak of paroxysm 3 and the onset of paroxysm 7, respectively, and 13.1 units from subject No. 18 for the peak of paroxysm 7 . The variations in urobilinogen excretion were large, even between samples collected only a few 
TABLE VII

Summary of the urobilinogen data, in Ehrlich units per two-hour urine collection, for the 12 subjects

\begin{tabular}{l|c|c|c|c|c}
\hline \multirow{2}{*}{ Item . } & \multirow{2}{*}{ Control } & \multicolumn{2}{|c|}{ Paroxysms } & \multicolumn{2}{|c}{ Post-quinine days } \\
\cline { 3 - 6 } \cline { 3 - 5 } & & $1-2$ & $5-8$ & $2-3$ & $4-7$ \\
\hline Mean & 1.16 & 3.62 & 5.20 & 2.31 & 1.66 \\
S.D. (土) & 0.35 & 3.95 & 5.55 & 1.13 & 1.81 \\
\hline
\end{tabular}

hours apart. Though there was a tendency for higher values to be found at the peaks of the paroxysms, this was by no means an invariable rule.

The relation between urobilinogen excretion and the stage of the malaria is indicated in Table VII. Elevated urobilinogen excretions were recorded within a few hours of the onset of fever in most of the men and this elevation tended to become progressively greater as malaria continued, but the course of progression was irregular in the several individuals.

In the first two or three days after quinine the urobilinogen excretion decreased in all men but only one out of 13 determinations fell within the normal range at that time. Four to seven days after quinine only five out of 12 determinations were still above the normal range, the highest values at that time being 7.2 and 2.1 units in subjects Nos. 17 and 8, respectively.

\section{DISCUSSION}

The results presented here combine to give a picture of the extent and character of the liver dysfunction produced by this type of malaria. It should be realized, however, that the degree of actual liver impairment or "damage" is not necessarily proportional to the degree of abnormality in the values obtained by the several tests. This is particularly clear in the case of the plasma bilirubin which may be elevated because of an abnormal load as well as, or even instead of, a reduced ability of the liver to clear the blood of this pigment.

If the average life span of the human erythrocyte is taken as 120 days, then the normal individual with a blood hemoglobin concentration of $15 \mathrm{gms}$. per $100 \mathrm{cc}$. and a blood volume of 6 liters must be disposing of some 7.5 gms. of hemoglobin daily. Since the degradation of $1 \mathrm{gm}$. of hemoglobin re- sults in the production of about $42 \mathrm{mg}$. of bilirubin (20), we would conclude that the normal man's liver must "process" about $310 \mathrm{mg}$. of bilirubin daily. But in the present subjects the active course of malaria for about eight days resulted in a decrease in the blood hemoglobin concentration amounting to an average of 2.4 gms. per $100 \mathrm{cc}$., and at the same time the total blood volume decreased from an average of 6,118 to one of 5,572 cc. This loss of $161 \mathrm{gms}$. of hemoglobin in eight days would indicate that, on the average, the livers of these men had to dispose of the bilirubin derived from approximately $27.5 \mathrm{gms}$. of hemoglobin each day. Instead of a normal daily task of clearing the blood of $310 \mathrm{mg}$. of bilirubin, the livers of these men during malaria were called on to handle a load of about $1,150 \mathrm{mg}$., that is, almost four times the normal load. In this connection it is significant that, in general, the level of serum bilirubin at any one time in malaria has been stated to be related to the rate of blood destruction (21).

This does not mean that the liver function of eliminating bilirubin was unimpaired in this experiment. The capacity of the normal liver to eliminate bilirubin is large as indicated by the absence of hyperbilirubinemia in some hemolytic states $(20,22)$. Studies on the results of the intravenous injection of hemoglobin-saline solutions are also of interest in this regard. In a few cases Amberson et al. (23) have injected amounts of hemoglobin which might be comparable to the present studies in regard to the imposition on the liver of a large load of hemoglobin degradation products. In only one patient "faint icterus" was produced. The most reasonable conclusion from the present data would be that there was some impairment of the liver function in eliminating bilirubin but that this was not great; a substantial part of the increase in plasma bilirubin concentration may be ascribed simply to the high rate of blood destruction.

The development of a positive Hanger test (cephalin-cholesterol flocculation) in malaria has been reported repeatedly $(7,19,24,25)$. In this test, as in the thymol turbidity test, it is probable that the reactions depend upon changes in the serum proteins and are not, accordingly, specific tests of liver function except in so far as the latter is reflected by qualitative or quantitative changes in the serum proteins. 
An important, and perhaps decisive, factor in the production of a positive cephalin-cholesterol flocculation test has been reported to be the amount of the several protein fractions present in the blood serum. Several laboratories have shown that the addition to normal blood serum of electrophoretically separated gamma globulin produces a positive flocculation in the cephalin-cholesterol test and have indicated that the albumin fraction tends to inhibit the flocculation (26-30). It is of interest therefore to examine the situation in the present material. For this purpose we have data on both the flocculation tests and the electrophoretic patterns of samples drawn when quinine was first administered to terminate the malaria. The details of the electrophoretic method have been reported previously (1). Figure 1 shows the correlation between the Hanger test and the percentage of the total protein fraction represented by gamma globulin. Within the limits of error, the relation is linear. The Hanger test results here apparently were not related to either the albumin or total protein concentrations. This does not necessarily deny the importance of the concentration of the albumin fraction since in the present study neither the albumin nor the total protein concentration showed major changes at any time in these subjects (cf. Taylor et al. [1]) ; the range in the samples on which Figure 1 is based was only from 6.28 to $7.47 \mathrm{gms}$. of total protein per $100 \mathrm{cc}$. of serum. It may be noted that the four serum samples which gave the highest cephalin flocculation values (Fig-

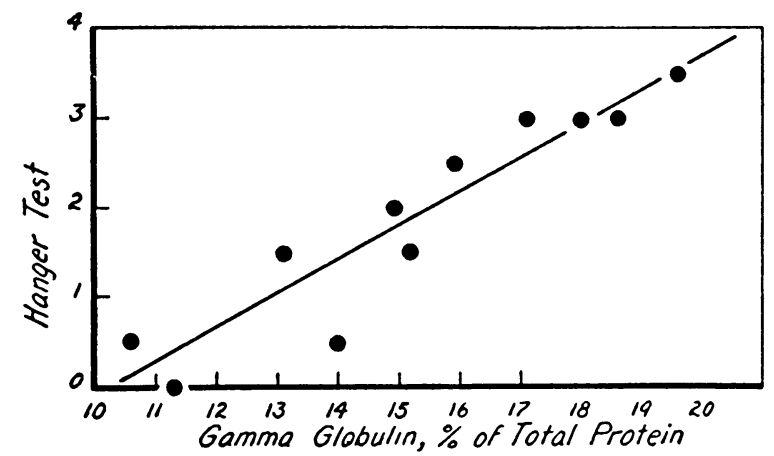

Fig. 1. The Relation Between the CephalinCholesterol Flocculation (Hanger) Test Result and the Percentage of the Total Serum Protein Represented by Gamma Globulin.

All values relate to the day on which malaria was terminated with quinine. Each Hanger test value is the mean of 24-hour and 48-hour readings. The trend line is the least-squares best linear fit. ure 1) all gave $2+$ turbidity in the thymol test; the other serums all gave $1+$ values.

Bromsulfalein retention has been reported both during and after induced malaria $(7,24,29)$; the phenomenon is similar in natural malaria (19). In natural $P$. falciparum malaria, Machella (31) found bromsulfalein retention during the febrile stage but not in the afebrile stage (remission), nor two or three days after the introduction of therapy (atabrine). Further indication of the importance of the fever per se was gained by the appearance of retention in normal men made febrile by the injection of triple typhoid vaccine. In the present study it was found that the bromsulfalein retention rapidly returned to normal after quinine but detailed comparisons of the retention in the febrile and afebrile stages of the paroxysms in nine cases showed no relation to the body temperature at the time. Reconciliation of this apparent difference from Machella's report is possible if it is suggested that fever is a major factor in producing the retention initially but that the changes involved are not reversed in the relatively short interludes between paroxysms which occurred in the present study.

\section{SUM MARY}

1. Tertian malaria was produced in 12 young men, previously normal, by inoculation with the McCoy strain of Plasmodium vivax, and was terminated with quinine after five to eight paroxysms.

2. Systematic evaluations of liver function were made from measurements of plasma bilirubin, urine bilirubin and urobilinogen, cephalin-cholesterol flocculation and thymol turbidity in the serum, and bromsulfalein excretion tests.

3. Prompt and delayed reacting plasma bilirubin rose, respectively, from mean control values of 0.069 and $0.76 \mathrm{mg}$. per $100 \mathrm{cc}$. to 0.19 and 1.39 in the first paroxysms of fever, and to means of 0.20 and 1.60 in paroxysms 4 through 7 .

4. Bilirubinuria did not occur.

5. Urobilinogen excretion rose progressively from a control average of 1.16 Ehrlich units in twohour collections to a mean of 2.73 units in the first febrile stages and a mean of 5.59 units for fever paroxysms 4 through 7 .

6. Both plasma bilirubin and urobilinogen excretion returned to normal within a week from the start of quinine. 
7. Bromsulfalein retention (45 minutes) averaged 8.9 per cent in the early febrile stages and 11.3 per cent for paroxysms 4 through 7 . Normal values were regained in a very few days after quinine.

8. Thymol turbidity values consistently rose in malaria but did not surpass upper "normal" values.

9. Cephalin-cholesterol flocculation values became progressively abnormal after several febrile paroxysms and, in most cases, were highest in the first weeks following quinine.

10. In malaria the liver had a load of about four times the normal amount of degraded hemoglobin to dispose of and it was concluded that the plasma bilirubin values found here represented only a moderate degree of actual impairment of the liver.

11. There was a good correlation in malaria between cephalin flocculation results and the percentage of the serum protein represented by gamma globulin.

12. None of the test results showed a significant correlation with either the actual body temperature at the moment or the total fever (degreehours).

\section{BIBLIOGRAPHY}

1. Taylor, H. L., Mickelsen, O., and Keys, A., The effects of induced malaria, acute starvation and semi-starvation on the electrophoretic diagram of the serum proteins of normal young men. J. Clin. Invest., 1949, 28, 273.

2. Henschel, A. Taylor, H. L., and Keys, A., Experimental malaria in man. I. Physical deterioration and recovery. J. Clin. Invest., 1950, 29, 52.

3. Ducci, H., and Watson, C. J., Quantitative determination of serum bilirubin with special reference to prompt-reacting and chloroform-soluble types. J. Lab. \& Clin. Med., 1945, 30, 293.

4. Malloy, H. T., and Evelyn, K. A., The determination of bilirubin with the photoelectric colorimeter. J. Biol. Chem., 1937, 119, 481.

5. Neefe, J. R., and Reinhold, J. G., Laboratory aids in the diagnosis and management of infectious (epidemic) hepatitis. Analysis and results obtained by studies on 34 volunteers during the early and convalescent stages of induced hepatitis. Gastroenterology, 1946, 7, 393.

6. Watson, C. J., and Hoffbauer, F. W., Liver function in hepatitis. Ann. Int. Med., 1947, 26, 813.

7. Fredricks, M. G., and Hoffbauer, F. W., A study of hepatic function in therapeutic malaria. J. A. M. A., 1945, 128, 495.
8. Cook, C. D., and Hoffbauer, F. W., Liver functional impairment in therapeutic malaria with particular reference to the unsuccessful use of methionine as a protective agent. J. Lab. \& Clin. Med., 1946, $31,56$.

9. Hawkinson, V., Watson, C. J., and Turner, R., A modification of Harrison's test for bilirubin in urine especially suited for mass and serial usage. J. A. M. A., 1945, 129, 514.

10. Fellinger, K., and Menkes, K., Ueber quantitative Bilirubinbestimmungen in Harn mit der Methylenblaumethod. Wien. klin. Wchnschr., 1933, 46, 133.

11. O'Leary, P. A., Greene, C. H., and Rowntree, L. G., Diseases of the liver. VIII. The various types of syphilis of the liver with reference to tests for hepatic function. Arch. Int. Med., 1929, 44, 155.

12. Mateer, J. G., Baltz, J. I., Marion, D. F., and MacMillan, J. M., Liver function tests : general evaluation of liver function tests; an appraisal of comparative sensitivity, and reliability of newer tests, with particular emphasis on cephalin-cholesterol flocculation test, intravenous hippuric acid test and improved bromsulphalein test with new normal standard. J. A. M. A., 1943, 121, 723.

13. Hanger, F. M., Serological differentiation of obstructive from hepatogenous jaundice by flocculation of cephalin-cholesterol emulsions. J. Clin. Invest., 1939, 18, 261.

14. Maclagan, N. F., The thymol turbidity test; new indicator of liver dysfunction. Brit. J. Exper. Path., 1944, 25, 234.

15. Watson, C. J., Schwartz, S., Sborov, V., and Bertie, E., Studies of urobilinogen. V. A simple method for the quantitative recording of the Ehrlich reaction as carried out with urine and feces. Am. J. Clin. Path., 1944, 14, 605.

16. Watson, C. J., and Hawkinson, V., Studies of urobilinogen. VI. Further experiences with the simple quantitative Ehrlich reaction. Corrected calibration of the Evelyn colorimeter with a pontacyl dye mixture in terms of urobilinogen. Am. J. Clin. Path., 1947, 17, 108.

17. Korteweg, P. C., Zur Frage des Gametengehaltes bei verschiedenen Plasmodienstämmen und ihres Rückganges bei mehreren Menschenpassagen. Wien. klin. Wchnschr., 1930, 43, 801.

18. Watson, C. J., Some newer concepts of the natural derivatives of hemoglobin; general considerations; serum bilirubin and bilirubinuria; erythrocyte protoporphyrin. Blood, 1946, 1, 99.

19. Lippincott, S. W., Ellerbrook, L. D., Hesselbrock, W. B., Gordon, H. H., Gottlieb, L., and Marble, A., Liver function tests in chronic relapsing vivax malaria. J. Clin. Invest., 1945, 24, 616.

20. Watson, C. J., The pyrrol pigments with particular reference to normal and pathological hemoglobin metabolism, in: Handbook of Hematology, edited by Downey, Hal. Paul B. Hoeber, Inc., New York, 1938, p. 2447. 
21. Fairley, N. H., Liver insufficiency in malaria. Congrès International de l'Insuffisance hepatique. A. Wallon, Vichy, Paris, 1937, Vol. 1, 189.

22. Miller, E. B., Singer, K., and Dameshek, W., Use of the daily fecal output of urobilinogen and the hemolytic index in the measurement of hemolysis. Arch. Int. Med., 1942, 70, 722.

23. Amberson, W. R., Jennings, J. J., and Rhode, C. M., Clinical experience with hemoglobin-saline solutions. Applied Physiol., 1949, 1, 469.

24. Kopp, I., and Solomon, H. C., Liver function in therapeutic malaria. Am. J. M. Sc., 1943, 205, 90.

25. Mirsky, I. A., von Brecht, R., and Williams, L. D., Hepatic dysfunction in malaria. Science, 1944, 99, 20.

26. Kabat, E. A., Moore, D. H., and Landow, H., An electrophoretic study of the protein components in cerebrospinal fluid and their relationship to the serum proteins. J. Clin. Invest., 1942, 21, 571.
27. Kabat, E. A., Hanger, F. M., Moore, D. H., and Landow, $H$., The relation of cephalin flocculation and colloidal gold reactions to the serum proteins. J. Clin. Invest., 1943, 22, 563.

28. Moore, D. B., Pierson, P. S., Hanger, F. M., and Moore, P. H., Mechanism of the positive cephalincholesterol flocculation reaction in hepatitis. $\mathrm{J}$. Clin. Invest., 1915, 24, 292.

29. Guttman, S. A., Potter, H. R., Hanger, F. M., Moore, D. B., Pierson, P. S., and Moore, D. H., Significance of cephalin-cholesterol flocculation test in malarial fever. J. Clin. Invest., 1945, 24, 296.

30. Wunderly, C., and Wuhrmann, F., The effect of experimental increases in the $\boldsymbol{\gamma}$-globulin and albumin content of sera on the response given by turbidity and flocculation tests. Brit. J. Exper. Path., 1947, 28, 286.

31. Machella, T. E., The relationship of bromsulphalein retention to the fever of natural $P$. falciparum malaria. Am. J. M. Sc., 1947, 213, 81. 